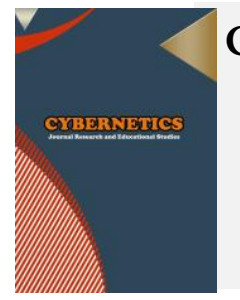

Cybernetics: Journal Educational Research and Social Studies

Volume 1, Nomor 1, Oktober 2020

Journal Homepage: http://pusdikra-publishing.com/index.php/jrss

\title{
EFEKTIVITAS PENGELOLAAN PERPUSTAKAAN DALAM MENINGKATKAN LAYANAN PENDIDIKAN DI MAN 2 LANGKAT
}

\author{
Irma Dahriah', Ahmad Zaki ${ }^{2}$, Abdullah Sani Kurniadinata ${ }^{3}$ \\ 1,2,3,STAI Jam'iyah Mahmudiyah
}

\begin{tabular}{ll}
\hline \multicolumn{1}{c}{ ABSTRACT } \\
\cline { 2 - 2 } & \multicolumn{1}{c}{ Penelitian ini bertujuan untuk mengetahui Efektifitas Pengelolaan } \\
Perpustakaan Dalam Meningkatkan Layanan Pendidikan Di MAN 2 \\
Langkat, Penelitian yang dilakukan ini adalah penelitian deskriptif \\
kualitatif. Penelitian deskriptif kualitatif mencoba mencari deskripsi yang \\
tepat dan cukup dari semua aktivitas, objek, proses, dan manusia. \\
Penelitian ini berupaya menggambarkan efektivitas atau hasil akhir dari \\
pengelolaan dan pelayanan di perpustakaan MAN 2 Langkat. Hasil \\
penelitian adalah Implementasi yang dilakukan kepala sekolah dalam \\
memenuhi sarana perpustakaan telah cukup baik dalam memenuhi \\
kebutuhan bahan pustaka dan mencari sumber daya manusia yang cukup \\
baik dalam mengelola perpustakaan MAN 2 Langkat. Dan pengarahan \\
dalam bentuk meningkatkan minat baca kepada siswa maupun tenaga \\
pendidik. Pustakawan MAN 2 Langkat telah berusaha meningkatkan \\
pengelolaan perpustakaan dengan cukup baik, walau hanya sebatas \\
mengelola bahan pustaka yang tersedia, serta memotivasi siswa untuk \\
berkunjung keperspustakaan bekerja sama dengan para guru mata \\
pelajaran, dan selalu berkomunikasi dengan kepala sekolah, jika ada \\
kesulitan maupun ada yang dibutuhkan. Dalam minat baca siswa MAN 2 \\
Langkat masih kurang dalam mintanya karena kurangnya dorongan dari \\
Guru dan buku terbaru kurang variatif. \\
\hline Efektifitas, Pengelolaan, Perpustakaan, Layanan Pendidikan \\
\end{tabular}

\section{PENDAHULUAN}

Kemampuan dalam menghadapi era globalisasi menjadi permasalahan utama yang saat ini dihadapi oleh bangsa Indonesia khususnya dalam bidang pendidikan, mengingat kualitas sumber daya manusia yang dimiliki sangat rendah. Mutu generasi emas akan menjadi modal dasar bagi daya saing bangsa. "Rendahnya kualitas generasi emas (SDM) yang dimiliki disebabkan karena rendahnya mutu pendidikan yang ada. Karena peningkatan mutu generasi emas hanya dapat melalui pendidikan yang bemutu (Wibowo, 2012).

Pendidikan merupakan usaha sadar dan terencana untuk mewujudkan suasana belajar dan proses pembelajaran agar peserta didik secara aktif mengembangkan potensi dirinya untuk memiliki kekuatan spiritual keagamaan, pengendalian diri, kepribadian, kecerdasan, akhlak mulia, serta keterampilan yang diperlukan dirinya, masyarakat, bangsa dan Negara (UUD No 20 2013). 
Salah satu permasalahan pendidikan yang dihadapi oleh bangsa Indonesia adalah rendahnya mutu pendidikan pada setiap jenjang dan satuan pendidikan, khususnya pendidikan dasar dan menengah. "Berbagai usaha telah dilakukan untuk meningkatkan mutu pendidikan nasional, misalnya pengembangan kurikulum nasioanal dan lokal, peningkatan kompetensi guru melalui pelatihan, pengadaan buku dan alat pelajaran, pengadaaan dan perbaikan sarana dan prasarana pendidikan, dan peningkatan mutu manajemen sekolah (Depdiknas, 2007)."

Perpustakaan sekolah merupakan bagian penting dari salah satu komponen pendidikan yang tidak dapat dipisahkan keberadaannya dari lingkungan sekolah. Sebagai salah satu sarana pendidikan perpustakaan sekolah berfungsi sebagai penunjang kegiatan siswa, membantu siswa dan guru dalam memacu tercapainya tujuan pendidikan di sekolah. Pentingnya perustakaan sekolah dapat dilihat dalam UU No 2 Tahun 1989 tentang sistem pendidikan nasional, dinyatakan bahwa setiap satuan pendidikan jalur pendidikan sekolah yang diselenggarakan oleh pemerintah maupun masyarakat harus menyedikan sumber belajar (Darmono, 2018).

Perpustakaan adalah pelayanan, tidak ada pelayanan jika tidak ada perpustakaan. Kegiatan melayani pembaca atau pemakai jasa perpustakaan secara tepat dan akurat disebut sebagai profesi pustakawan. Sementara itu, Indonesia juga membuat suatu aturan mengenai kewajiban seorang pengusaha penerbitan dan pengusaha rekaman untuk menyerahkan bukti karyanya pada perpustakaan.

Dalam Undang-Undang No.2 tahun 1989 tentang eksistensi perpustakaan yaitu pasal 35, disebutkan bahwa "setiap satuan pendidikan, jalur pendidikan sekolah yang diselenggarakan oleh pemerintah maupun masyarakat harus menyediakan sumber belajar". Pada penjelasan Undang-Undang No. 2 tahun 1989 tersebut juga dinyatakan bahwa pendidikan tidak mungkin terselenggara dengan baik apabila tenaga kependidikan maupun para peserta didik tidak didukung oleh sumber belajar yang diperlukan untuk penyelenggaraan kegiatan belajar mengajar yang bersangkutan.

Perpustakaan sekolah tentunya memiliki berbagai macam koleksi baik yang berbentuk buku maupun non buku, koleksi tersebut dapat dilihat dari segi kepentingannya, pemanfaatannya, dan kebutuhan pemakainya. Semua koleksi tersebut perlu diolah sebelum disajikan kepada pemustaka. Pengolahan koleksi pada suatu perpustakaan dimaksudkan agar semua koleksi yang ada dapat dimanfaatkan dengan mudah oleh para pemakai perpustakaan. Untuk kegiatan pengolahan koleksi dapat dipikirkan supaya mekanisme yang menghubungkan koleksi sebagai media informasi dengan pembaca sesuai 
dengan disiplin ilmu yang diinginkan.

Oleh karena itu proses pembelajaran dalam penyelenggaraan pendidikan harus dikelola secara profesional agar tercapainya mutu pendidikan yang diharapkan. Berdasarkan tabel dari laporan UNESCO Education For All Global Monitoring Report 2012, "kualitas pendidikan Indonesia berada di peringkat ke- 64 dari 120 negara di seluruh dunia." Banyak bangsa yang telah maju karena mereka menguasai informasi yang dibutuhkannya. Untuk itulah informasi perlu diperkenalkan dan mulai ditanamkan kepada peserta didik di sekolah.

Namun sikap gemar membaca yang dimiliki bangsa Indonesia masih relatif rendah. "Hal ini sesuai dengan hasil survei yang dilakukan UNDP terhadap 41 negara misalnya, menempatkan Indonesia pada posisi 39" (Rasyidin, 2005). Sekolah sebagai lembaga pendidikan formal seharusnya dapat membantu meningkatkan minat baca peserta didiknya, maka dari itu perlu adanya pengembangan sistem belajar di Indonesia dengan memanfaatkan pelayanan yang diberikan oleh perpustakaan sekolah. "Dalam keseluruhan proses pendidikan di sekolah, kegiatan belajar merupakan kegiatan yang paling pokok. Ini berarti bahwa berhasil tidaknya pencapaian tujuan pendidikan bergantung kepada bagaimana proses belajar yang dialami oleh siswa sebagai anak didik."

Keterbatasan waktu dalam menyampaikan materi pelajaran di sekolah (di dalam kelas) menyebabkan semakin berkurangnya informasi yang diterima oleh peserta didik dalam proses belajar mengajar yang akhirnya akan berpengaruh pada prestasi peserta didik dan mutu sekolah itu sendiri.

Proses pembelajaran seharusnya tidak hanya terpaku belajar di dalam kelas dengan menggunakan metode ceramah, proses pembelajaran dapat dilakukan dengan memanfaatkan berbagai sarana, salah satunya dengan memanfaatkan perpustakaan sebagai sarana penunjang dalam proses pembelajaran yang telah disediakan oleh sekolah. Misalnya seperti memanfaatkan ruang perpustakaan sebagai ruang belajar agar siswa dapat mencari referensi buku-buku. Dengan demikian secara tidak langsung guru telah memberikan stimulus kepada siswa untuk mulai membaca. Hal tersebut sejalan dengan pemikiran Sutarno dimana perpustakaan sekolah diselenggarakan oleh sekolah dan pemanfaatannya sangat bergantung kepada upaya kepala sekolah, para guru, petugas perpustakaan dan para pelajar.

Dengan adanya perpustakaan sekolah, siswa dan guru harus selalu sadar bahwa ilmu pengetahuan yang mereka dapatkan tidak terbatas pada dinding ruang kelas saja. Dengan demikian ilmu pengetahuan dan pengalaman dapat diperkaya karena mereka tidak membatasi diri pada materi-materi yang 
terkandung dalam buku pelajaran yang umumnya diwajibkan oleh guru atau pihak lain yang bersangkutan. Hal tersebut akan membuat suasana belajar lebih menyenangkan dan siswa pun akan tertarik pada bahan-bahan yang diajarkan.

Perpustakaan sebagai salah satu sarana dalam menunjang proses belajar dan mengajar di sekolah harus terus melakukan upaya pemberdayaan pelayanan yang baik guna tercapainya tujuan perpustakaan yang tertera dalam UU no 43 Tahun 2007 "Perpustakaan merupakan institusi pengelola koleksi karya tulis, karya cetak, dan/atau karya rekam secara profesional dengan sistem yang baku guna memenuhi kebutuhan pendidikan, penelitian, pelestarian, informasi, dan rekreasi para pemustaka."

Secara umum kegiatan belajar-mengajar di MAN meliputi teori dan praktik. Kegiatan belajar teori pada prinsipnya sama dengan sekolah menengah atas (SMA). Salah satu hal yang perlu dipersiapkan untuk menunjang keberhasilan pelaksanaan pembelajaran di lingkungan Madrasah Aliyah Negeri (MAN) adalah keberadaan perpustakaan sekolah yang berfungsi secara baik. Dalam penerapan pembelajaran banyak ditemui berbagai permasalahan lapangan salah satunya adalah ketersediaan bahan pelajaran untuk menunjang proses pembelajaran masih harus perlu dispersiapkan dengan baik. Dengan demikian peran layanan perpustakaan sangat dibutuhkan di lingkungan sekolah sebagai penunjang keberhasilan proses belajar mengajar.

"Perpustakaan sekolah adalah satu bentuk organisasi sumber belajar di sekolah yang menghimpun berbagai informasi dalam bentuk buku dan bukan buku yang dapat dimanfaatkan oleh pemakai (guru, dan siswa) dalam upaya mengembangkan kemampuan dan kecakapan."

Perpustakaan sekolah dewasa ini bukan hanya merupakan unit kerja yangmenyediakan bacaan guna menambah pengetahuan dan wawasan bagi murid, tapi juga merupakan bagian yang integral pembelajaran. Artinya, penyelenggaraan perpustakaansekolah harus sejalan dengan visi dan misi sekolah dengan mengadakan bahan bacaanbermutu yang sesuai kurikulum, menyelenggarakan kegiatan yang berkaitan dengan bidangstudi, dan kegiatan penunjang lain, misalnya berkaitan dengan peristiwa penting yangdiperingati di sekolah.

Para siswa dan guru merupakan target utama dari berbagai pelayanan yang diberikan oleh pihak perpustakaan. Hal tersebut sejalan dengan undangundang nomor 43 tahun 2007 yang menjelaskan bahwa perpustakaan sekolah/madrasah melayani peserta didik pendidikan kesetaraan yang dilaksanakan di lingkungan satuan pendidikan yang bersangkutan. oleh karena itu pelayanan berbasis kebutuhan pengguna merupakan faktor yang sangat 
penting untuk dijadikan pertimbangan dari berbagai pelayanan perpustakaan guna menunjang proses pembelajaran.

MAN 2 Langkat merupakan sebuah lembaga pendidikan yang berkomitmen dalam meningkatkan mutu pendidikan. Berbagai macam upaya telah dilakukan lembaga ini, antara lain adalah memberikan pelatihan baik untuk tenaga pendidik maupun tenaga kependidikan yang ada di lingkungan sekolah agar meningkatkan kemampuan kinerja tenaga pendidik dan tenaga kependidikan tersebut. Untuk meningkatkan kualitas pembelajaran, MAN 2 Langkat tidak hanya memperhatikan sumber daya manusia yang ada, akan tetapi juga melalui komponen penunjang lainnya, yaitu melalui sarana dan prasarana sekolah. Salah satunya adalah mengoptimalkan layanan perpustakaan sekolah.

Banyak Madrasah Aliyah yang belum siap dengan penyediaan bahan pelajaran melalui perpustakaan sekolah. Ketidaksiapan tersebut bukan sematamata disebabkan kurangnya bahan pelajaran (buku pelajaran dan sumber informasi ilmiah lainnya), akan tetapi juga disebabkan oleh pengelolaan perpustakaan yang kurang baik dan terstandar, dan kurangnya tenaga kependidikan yang ahli dibidang perpustakaan sehingga koleksi yang sudah dimiliki kurang dapat didayagunakan untuk menunjang pelaksanaan kurikulum secara maksimal. Begitu juga dengan perpustakaan sekolah yang terdapat di Madrasah Aliyah Negeri (MAN) 2 Langkat. Oleh karena itu penulis melakukan penelitian mengenai “Efektifitas Pengelolaan Perpustakaan Dalam Meningkatkan Layanan Pendidikan Di MAN 2 Langkat".

\section{METODE PENELITIAN}

Penelitian yang dilakukan ini adalah penelitian deskriptif kualitatif. Penelitian deskriptif kualitatif mencoba mencari deskripsi yang tepat dan cukup dari semua aktivitas, objek, proses, dan manusia. Penelitian ini berupaya menggambarkan efektivitas atau hasil akhir dari pengelolaan dan pelayanan di perpustakaan MAN 2 Langkat.

Untuk memperoleh data yang signifikan dalam penelitian ini, digunakan teknik-teknik pengumpulan data sebagai berikut:

1) Observasi, teknik ini digunakan untuk mendata situasi dan kondisi proses layanan perpustakaan dalam menunjang proses pembelajaran. Melalui pengamatan langsung diperoleh gambaran secara umum mengenai mata pelajaran apa saja yang menggunakan perpustakaan sekolah dalam proses pembelajaran, sistem layanan yang digunakan oleh perpustakaan serta jenis layanan perpustakaan, seperti menyediakan ruang baca, adanya layanan sirkulasi, menyediakan 
layanan referensi, serta mengaplikasikanlayanan berbasis teknologi informasi dan komunikasi guna menunjang proses pembelajaran di sekolah.

2) Wawancara, dalam hal ini wawancara dilakukan dengan tenaga kependidikan dibidang perpustakaan untuk memperoleh informasi mengenai kegiatan perpustakaan sekolah.

\section{HASIL DAN PEMBAHASAN}

\section{Manajemen Perpustakaan MAN 2 Langkat Tanjung Pura Kabupaten Langkat}

Manajemen Perpustakaan cukup beragam. Oleh karena itu perlu adanya penjabaran terlebih dahulu fungsi manajemen perpustakaan dalam meningkatkan minat baca ialah mengelola perpustakaan secara baik dan optimal, Menurut Undang- undang No. 43 tahun 2007, perpustakaan sekolah merupakan salah satu jenis dari perpustakaan khusus. Ciri-ciri perpustakaan khusus, antara lain adalah diperuntukkan secara terbatas bagi pemustaka di lingkungan lembaga pemerintah, lembaga masyarakat, lembaga pendidikan keagamaan, rumah ibadah, atau organisasi lain.

Perpustakaan sekolah menurut Standar Nasional Indonesia, adalah perpustakaan yang berada pada satuan pendidikan formal di lingkungan pendidikan menengah, yang merupakan bagian integral dari kegiatan sekolah yang bersangkutan, dan merupakan pusat sumber belajar untuk mendukung tercapainya tujuan pendidikan sekolah yang bersangkutan. Definisi yang sama juga, bahwa perpustakaan sekolah adalah perpustakaan yang tergabung pada sebuah sekolah, dikelola sepenuhnya oleh sekolah yang bersangkutan, dengan tujuan utama membantu sekolah untuk mencapai tujuan khusus sekolah dan tujuan pendidikan pada umumnya. Perpustakaan sekolah merupakan sarana bagi para murid agar terampil belajar sepanjang hayat dan mampu mengembangkan daya pikir agar mereka dapat hidup sebagai warga negara yang bertanggung jawab.

Salah satu manajemen perpustakaan yang sering dilakukan oleh Kepala sekolah Bapak Edi Sahputra, S.Pd, MM dan Pustakawan MAN 2 Langkat Tanjung Pura Ibu Mariatul Qibtiyah, S.Pd adalah : memilih sumber daya manusia yang ada dengan cara diberi tes secara praktek dan di awasi oleh Kepala Sekolah langsuung dan Waka Kurikulum, jika layak maka calon pustakawan langsung diberi tugas untuk mengelola perpustakaan secara optimal. Karena dengan adanya pustakawan manajemen perpustakaan akan berjalan dengan, baik.

Walau perpustakaan MAN 2 Langkat disini masih minim pustakawan tetap berusaha memanajemen secara baik walau masih banyak 
kekurangan, dan selalu berkomunikasi dengan Kepala Sekolah Jika ada bahan pustaka yang diperlukan. Pustakawan sendiri hanya mengelola bahan pustaka yang tersedia di perpustakaan MAN 2 Langkat walau terbatas. Ruangan yang nyaman sangatlah penting bagi pengunjung perpustakaan agar tidak jenuh dan bosan, karena ruangan yang terdapat di perpustakaan MAN 2 Langkat sangat kecil dan panas, pustakawan berusaha menghubungi kepala sekolah untuk dipasang kipas angin dan penambahan kursi meja, dan buku - buku novel yang menarik sebagai memotivasi para siswa agar berkunjung ke perpustakaan.

MAN 2 langkat juga melaksanakan gerakan membaca senyap. Kegiatan ini akan dilaksanakan di lapangan MAN 2 Langkat setiap selasa pagi sebelum para siswa memulai pelajaran di kelas masing-masing. Dalam kegiatan ini para siswa dan guru diberi waktu untuk membaca buku bacaan yang dibawa masing-masing. Setelah membaca akan diberi kesempatan kepada para peserta membaca senyap untuk menyampaikan pengalaman membacanya di panggung MAN 2 Langkat.

Program membaca senyap ini digagas oleh Ahmad Azhari yang merupakan pembina OSIS MAN 2 Langkat. Kegiatan ini diharapkan akan membentuk habbit atau kebiasaan berliterasi di lingkungan madrasah. Saat ini sama kita ketahui sudah banyak gerakan literasi digalakan dimana-mana oleh berbagai kalangan. MAN 2 Langkat ikut ambil bagian dalam gerakan positif ini guna mengembangkan mutu sumber daya manusia indonesia dari lingkungan terkecil yang ada yaitu madrasah ini. Ucap guru yang akrab dipanggil Azhari ini.

Tidak ada kata terlambat untuk maju dan berbuat kebaikan. Tambahnya. Kegiatan ini mendapat apresiasi dari kepala MAN 2 Langkat, Edi Sahputra, S.Pd.I MM. Kita akan terus dan terus berusaha semaksimal mungkin untuk memajukan madrasah dan seluruh warga MAN 2 Langkat. Kegiatan ini membuktikan semangat kita bersama dalam upaya memajukan mutu pendidikan khususnya di Madrasah kita. Jelasnya ketika diwawancarai oleh tim redaksi web man2-langkat.sch.id ini.

Membaca merupakan kegiatan yang sangat efektif untuk mengasah kemampuan berfikir. Dengan membaca otak akan terbiasa mencerna informasi dan memberi respon dari apa yang dibaca.

Perpustakaan MAN 2 Tanjung Pura pernah berhasil menyabet juara IV dalam Lomba Perpustakaan Prima dan Representatif Tingkat SLTA/MA/Sederajat se-Kabupaten Langkat Tahun 2017, yang di adakan tahun 2017. Beberapa kriteria dalam penilaian lomba yang yang di gelar oleh Dinas Kearsipan dan Perpustakaan Kabupaten Langkat tersebut diantaranya adalah 
meliputi penataan ruangan, administrasi perpustakaan, jumlah buku, dan kreatifitas sekolah dalam menjadikan perpustakaan sebagai wahana untuk menggali informasi ilmu bermanfaat bagi para peserta didik.

Setelah melakukan serangkaian penilaian tersebut, hari ini Senin $(4 / 12)$ para pemenang di berikan piagam penghargaan, trofi, dan sejumlah uang pembinaan. Hj. Mariatul Qibtiah, S.Pd selaku Kepala Perpustakaan MAN 2 Tanjung Pura mewakili perpustakaan MAN 2 Tanjung Pura menerima penghargaan yang diberikan oleh Bupati Langkat, H. Ngogesa Sitepu SH tersebut.

Kepala MAN 2 Tanjung Pura Drs. Sucipto Gito Siswanto, M.MPd (pada tahun 2017) berharap agar prestasi yang di capai untuk saat ini dapat menjadi motivasi bagi segenap jajaran pengurus perpustakaan untuk lebih meningkatkan kualitas perpustakaan sehingga menjadi lebih baik kedepannya. "Terutama bagi peserta didik, agar lebih memiliki minat baca yang tinggi," ujarnya.

Kepala Perpustakaan MAN 2 Langkat juga mengikuti dilkat. Untuk melakukan tindak lanjut dari kegiatan kursus atau diklat yang diikutinya, seorang peserta harus melakukan kegiatan lanjutan yang disebut dengan RTL (Rencana Tindak Lanjut). Pelaksanaan RTL bisa dilakukan dalam bentuk sosialisasi, seminasi, workshop, tutor sebaya dan pelaksanaan PTK. Untuk tujuan RTL tersebut, Kepala Perpustakaan MAN 2 Langkat, Mariatul Qibtiah, S.Pd melaksanakan sosialisasi hasil diklat kepala perpustakaan yang diikutinya di Jakarta tanggal 27 September s/d 14 Oktober di Balai Diklat Jakarta. Pelaksanaan sosialisasi diadakan pada Kamis, 25 Oktober 2018 bertempat di aula guru MAN 2 Langkat. Dihadiri oleh para guru dan wkm MAN 2 Langkat.

Dalam sosialisasinya Mariatul menyampaikan point- point penting yang ia peroleh pada kegiatan diklat dimaksud. Beliau menyampaikan pint penting tentang idealnya sebuah perpustakaan berkenaan dengan koleksi buku, sistem pelayanan dan penerapan IT di pelayanan Perpustakaan. "Tentu saja untuk membuat perpustakaan MAN 2 menjadi perpustakaan modern dan ideal seperti yang mereka sampaikan di diklat tidaklah semudah membalikkan telapak tangan. Segala sesuatunya membutuhkan perencanaan dan dana yang mencukupi. Untuk itu tentunya kita mengharapkan perhatian khusus dari kepala madrasah kita," ungkapnya. Selain itu menurutnya juga bahwa pada masa-masa mendatang, pemerintah secara khusus akan melaksanakan akreditasi untuk perpustakaan di madrasah dan sekolah. "Dengan adanya akreditasi perpustakaan tentu saja kita berharap memperoleh akreditasi yang 
sama statusnya dengan akreditasi yang diperoleh oleh madrasah kita," ungkapnya.

Sementara itu, Kepala MAN 2 Langkat, Edi Sahputra, S.Pd, MM menyampaikan ucapan selamat dan terimakasih serta apresiasi atas peran aktif Mariatul Qibtiah dalam kegiatan Diklat yang diadakan oleh Kemenag RI tersebut. Dia juga berterima kasih atas kerjasama para guru untuk mensukseskan pelaksanaan RTL yang dilakukan oleh Kepala Perpustakaan tersebut. Diharapkan juga keikutsertaan Mariatul Qibtiah dalam diklat dan sosialisasi yang disampaikannya kepada para guru MAN 2 Langkat akan berimbas positif dengan terjadinya perubahan yang signifikan dalam pengelolaan bahan pustaka dan pelayanan publik sehingga perpustakaan bisa berfungsi secara optimal yang pada gilirannya akan menunjang kemajuan MAN 2 Langkat secara keseluruhan. " Kita akan berusaha untuk memenuhi dan melengkapi kebutuhan perpustakan MAN 2 Langkat," ungkapnya.

\section{Faktor Penghambat Implmentasi Manajemen Perpustakaaan Dalam Meningkatkan MAN 2 Tanjung Pura Langkat}

Demikian pula apa yang di sampaikan oleh Kepala Sekolah, Edi Sahputra, S.Pd, MM. Penghambat dalam implementasi manajemen perpustakaan dan minat baca ialah kurangnya sarana didalam perpustakaan diantaranya Buku, yang kadang terlambat datang serta ruangan yang perlu diperbesar mengingat jumlah siswa yang semakin meningkat jumlahnya setiap tahunnya. Kami pernah ingin membuat ruangan perpustakaan yang lebih lebar tetapi kekurangan dana yang membuat kami belum terealisasi keinginan tersebut. Serta motivasi dari seorang pengajar sangat lah penting untuk, menunjang siswa agar berkunjung keperspustakaan dengan cara, memberi tugas meresume salah satu buku yang ada diperpustakaan, belajar diperpustakaan, atau setiap kali pertemuan siswa menyetor kepada guru setipa mata pelajaran buku apa yang ia pinjam di perpustakaan. Tetapi hal itu kurang dilakukan oleh para guru sehingga siswa agak jarang berkunjung keperpustakaan. Dan kurang menaruh perhatian terhadap perpustakaan, padahal perpustakaan ialah mobilitas untuk menunjang prestasi siswa untuk kedepan karena semua bidang karya ilmiah dan displin ilmu terkumpul disana.

Perpustakaan terkadang kurang dikunjungi untuk membaca bahkan meminjam buku karena buku yang ada tidak bervariasi judulnya atau untuk membangkitkan siswa sehingga siswa jenuh untuk meminjam, hal ini seharusnya juga di tunjang oleh para tenaga pendidik untuk terus memotivasi siswa agar terus, gemar membaca di perpustakaan.
Bentuk- Bentuk Implementasi Manajemen Perpustakaan Dalam Meningkatkan Minat Baca Peserta Didik Yang Dilakukan Oleh MAN 2 


\section{Langkat}

Madrasah Aliyah Negeri (MAN) 2 Langkat adalah sebuah madrasah yang termasuk cukup baik diwilayah Kabupaten Langkat Sumatera Utara. Untuk meningkatkan kualitas mutu pendidikan, harus mempunyai fasilitas yang mendukung kegiatan belajar mengajar. Fasilitas ini diantaranya adanya perpustakaan sekolah. Saat ini Sistem Pengelolaan Perpustakaan yang ada di MAN 2 Langkat masih Kurang sempurna untuk penunjang pengolahan data di perpustakaan dan menarik minat baca siswa, seorang pustakawan disini sangat berperan untuk menarik para siswa agar mendatangi perpustakaan dan membuat senyaman mungkin perpustakaan agar siswa yang berkunjung nyaman dalam berkunjung keperpustakaan Dan juga pencarian catalog buku masih menggunakan manual data inventaris buku juga masih kurang terkendali dan kurang nya dari peran seorang guru dalam memotivasi siswa agar mengunjungi perpustakaaan.

Berdasarkan hal tersebut diatas maka diperlukan adanya suatu system Pengeloloaan perpustakaan di MAN 2 Langkat. Penelitian ini bertujuan untuk memotivasi minat baca siswa dan menata perpustakaan dengan baik dan menyusun data - data inventaris buku system yang telah ada sehingga diharapkan dapat menarik minat siswa dan menata perpustakaan dengan baik sehingga dengan senyaman mungkin.

Usaha yang telah dilakukan oleh Kepala Sekolah dan Pustakawan dalam Pembinanaan minat baca. Disamping pembinaan perpustakaan sekolah, hal yang tidak kalah pentingnya untuk dilakukan dalam rangka meningkatkan minat baca adalah kegiatan-kegiatan yang dilakukan untuk meningkatkan minat membaca. Kegiatan tersebut dapat dikembangkan, dan sangat bergantung kepada kreativitas dan inisiatif tenaga pendidik di sekolah. Beberapa kegiatan yang dianjurkan telah di ajanjurkan oleh Pustakawan dan Kepala Sekolah Ialah :

1. Mengundang pustakawan dan para guru agar beerjasama dalam merencanakan kegiatan promosi minat baca.

2. Mengorganisasi lomba minat baca di sekolah.

3. Memilih siswa teladan yang telah membaca buku terbanyak.

4. Melaksanakan program wajib baca di sekolah.

5. Menjalin kerjasama antar perpustakaan sekolah.

6. Memberikan tugas baca setiap minggu dan melaporkan hasil bacaannya.

7. Menceritakan orang-orang yang sukses sebagai hasil membaca.

8. Menugaskan siswa untuk membuat abstrak dari buku-buku yang 
dibaca.

9. Menugaskan siswa belajar ke perpustakaan apabila guru tidak hadir.

10. Menerbitkan majalah/ buletin sekolah.

11. Mengajarkan teknik membaca kepada siswa.

12. Memberikan waktu khusus kepada siswa untuk membaca.

13. Menyelenggarakan pameran buku secara periodik.

14. Menulis Opini dan resume yang nantinya bila layak akan diterbitkan di media cetak.

Tetapi hal ini masih kurang efektif dilaksanakan hanya beberapa saja yang telah terlaksana.

\section{Analisis temuan penelitian}

Memanajemen perpustakaan MAN 2 Langkat cukup terealisasi diantara nya kepala sekolah berusaha dalam menyediakan bahan pustaka yang di butuhkan di dalam perpustakaan, tetapi hal ini masih ada yang kurang diantaranya perpustakaan yang kurang luas maupun penggunaan siswa dalam penggunaan buku dalam buku disiplin ilmu kurang dipergunakan, serta perlu variasi buku terbaru untuk meningkatkan minat baca siswa- siswi untuk berkunjung perpustakaan.

Ruang perpustakaan di MAN 2 Langkat yang direncanakan akan diperluas lagi gedungnya memiliki kendala biaya dalam pelaksanaannya. Guna menampung jumlah siswa yang semakin tahun, semakin meningkat jumlahnya sebagai minat antusias masyarakat sekitar terhadap MAN 2 Langkat Tanjung Pura.

\section{Pembahasan}

Memanajemen perpustakaan MAN 2 Langkat cukup terealisasi diantaranya kepala sekolah berusaha dalam menyediakan bahan pustaka yang dibutuhkan di dalam perpustakaan, tetapi hal ini masih ada yang kurang diantara gedung perpustakaan yang perlu diperluas, maupun penggunaan siswa dalam, penggunaan buku dalam buku disiplin ilmu kurang dipergunakan.

Ruang perpustakaan di MAN 2 Langkat yang direncanakan akan diperluas lagi gedungnya memiliki kendala biaya dalam pelaksanaannya. Guna menampung jumlah siswa yang semakin tahun, semakin meningkat jumlahnya sebagai minat antusias masyarakat sekitar terhadap MAN 2 Langkat Tanjung Pura.

Memanajemen untuk kelengkapan pustaka yang diperlukan dalam perpustakaan kurang jumlahnya dan kadang kala kurang tersusun dengan baik oleh siswa- siswa yang berkunjung. 
Jumlah buku dan untuk minat baca siswa jika dilihat berbanding sangat jauh yakni: 1750 buku berkunjung 193,dan peminjam 173, dengan jumlah siswa 545 , total siswa yang aktif ke perpustakaan ialah 366, ini agak jauh dari perbandingan buku yang tersedia dengan siswa yang meminjam dan membaca.

Control, planning yang dilakukan kurang maksimal, dikarenakan kurangnya jumlah tenaga pustakawan, diantaranya buku dari bantuan dari pemerintah kurang disusun dengan cepat, serta planning untuk keberlangsungan minat baca untuk siswa memerlukan waktu yang lama untuk di susun.

Penghambat dalam pelaksanaan implementasi manajemen perpustakaan dalam meningkatkan minat baca di MAN 2 Langkat ialah, kurangnya motivasi dari seorang guru mata pelajaran dalam membimbing muridnya untuk mendatngi perpustakaan untuk membaca padahal metode yang bisa digunakan untuk memotivasi ialah bisa saja memberikan tugas meresume buku yang ditugaskan oleh guru ataupun memberikan tugas setoran 3 hari sekali buku apa saja yang ia baca pada hari-hari kemarin, dan tatkala pentingnya sarana di perpustakaan kurang variasinya, keberadaanya karena kekurangan dana sehingga bahan pustaka kekurangan yang diperlukan di dalam perpustakaan MAN 2 Langkat.

Bentuk - bentuk yang dilakukan MAN 2 Langkat dalam pelaksanaan manajemen perpustakaan minat baca ialah, telah cukup baik dalam pengadaan bahan baca atau buku yang disiapkan untuk peserta didik maupun guru, untuk menunjang kegiatan belajar mengajar, dalam hal ini kepala sekolah, pustakawan, dan terlebih lagi para pengajar. Harus lah berperan aktif dalam melaksanakan kannya, seharusnya planning yang dilakukan atau yang sudah dibuat harus berkelanjutan, agar visi misi yang dibuat disekolah tercapai. Walaupun belum efektif harus berkelanjutan dalam peningkatan minat baca di MAN 2 Langkat. Dan dalam memanajemen perpustakaan MAN 2 Langkat haruslah efektif dalam pengelolaan dan mengkontrol semua bahan pustaka yang tersedia agar menarik bagi siswa untuk berkunjung.

\section{KESIMPULAN}

Berdasarkan laporan hasil penelitian dan analisis pada bab sebelumnya maka penelitian mengenai, implementasi manajemen perpustakaan dalam meningkatkan minat baca peserta didik di MAN 2 Langkat. Dapat di simpulkan Sebagai berkiut:

1. Implementasi yang dilakukan kepala sekolah dalam memenuhi sarana perpustakaan telah cukup baik dalam memenuhi kebutuhan bahan pustaka dan mencari sumber daya manusia yang cukup baik dalam 
mengelola perpustakaan MAN 2 Langkat. Dan pengarahan dalam bentuk meningkatkan minat baca kepada siswa maupun tenaga pendidik.

2. Pustakawan MAN 2 Langkat telah berusaha meningkatkan pengelolaan perpustakaan dengan cukup baik, walau hanya sebatas mengelola bahan pustaka yang tersedia, serta memotivasi siswa untuk berkunjung keperspustakaan bekerja sama dengan para guru mata pelajaran, dan selalu berkomunikasi dengan kepala sekolah, jika ada kesulitan maupun ada yang dibutuhkan.

3. Dalam minat baca siswa MAN 2 Langkat masih kurang dalam mintanya karena kurangnya dorongan dari Guru dan buku terbaru kurang variatif.

\section{DAFTAR PUSTAKA}

Departemen Agama RI, Al- Qur'an dan Terjemahnya Al- Jumanatul 'Ali (Seuntai Mutiara yang Maha Luhur, (Bandung: Cv. Penerbit Jumanatul 'Ali Art (JArt) 2005).

Hardjoesoedarmo Soewarso, Total Quality Management, (Yogyakarta: Andi Offest, 2006).

Ikapi, Himpunan Peraturan dan Perundng-undangan Tentang Guru dan Dosen, (Bandung: Fokusmedia).

Kompri, ManajemenPendidikan: Komponen-komponen Elementer Kemajuan Sekolah. Yogyakarta: Ar-Ruzz Media, 2016).

Kurniadin, Didin dan Imam machali, Manajemen Pendidikan: Konsep dan Prinsip Pengelolaan Pendidikan, (Yogyakarta: Ar-ruzz Media).

Kuswara, Deni dan Cepi Triyatna, Manajemen Pendidikan, (Bandung: Alfabeta, 2009).

Masyuri dan Zainuddin, Metodologi Penelitian (Pendekatan Praktis dan Aplikatif), (Bandung: PT Refika Aditama, 2008).

Matin, Dasar-dasar Perencanaan Pendidikan, (Jakarta: PT Rajagrafindo Persada, 2013.

Mulyasa.Manajemen Berbasis Madrasah: Konsep.Strategi, dan Implementasi, (Bandung: Remaja Rosdakarya. 2005).

Musaddad, Thontowi Djauhari, "Ilmu Pengetahuan dalam Pandangan Islam" Pelangi Pendidikan, Januari 2007.

Rohiat, Manajemen Sekolah, (Bandung: PT. Refika Aditama, 2010).

Rosady Ruslan, Metode Penelitian: public relations \& Komunikasi, (Jakarta: PT.Raja Grafindo Persada, 2008). 
Cybernetics: Journal Educational Research and Social Studies

Sallis, Edward, Manajemen Mutu Terpadu, (Yogyakarta: IRCiSoD, 2011).

Saud, Udin Syaefudin \& Abin Syamsuddin Makmun, Perencanaan Pendidikan Suatu Pendekatan Komprehensif, (Bandung: Remaja Rosdakarya, 2005).

Sitorus, Masganti, Metodologi Penelitian Pendidikan Islam, (Medan: IAIN PRESS, 2011).

Sugiyono, Metode Penelitian Kombinasi (Mixed Methods), (Bandung:Alfabeta, 2015). 